\title{
Evaluations of hotels and restaurants' guests of food risk management quality in Alexandria Nawal Morsi Zaki
}

High Institute for Tourism and Hotels in Alexandria (EGOTH)

Department of Hotels Studies

\begin{abstract}
The aim of this study is to evaluate the food risk management quality in Alexandria city through hotels and restaurants guests and the food safety knowledge of guests about factors that contribute to food poisoning outbreaks. The data were collected via two questionnaires, distributed to a sample of hotels and restaurants 'guests. The results generally confirm the importance of these factors, which help explain relative perceptions of well and poorly managed risks.
\end{abstract}

Key words: Food Safety, Food Risk Management, Guests' Evaluation, Food Poisoning

\section{Introduction}

Food safety has become one of the most important issues of the public concern worldwide, as various types of food safety related incidents reduced the consumer confidence in the healthiness of food products in recent years. Some studies report that the consumers are more concerned than ever by the food safety risks. ${ }^{(1,2,3)}$ consumers are becoming increasingly skeptical and concerned about the quality and safety of food, and appear to want information to help their choice.

It is important to understand how consumers $\backslash$ guests evaluate the quality of food risk management practices. The past occurrence of various food safety incidents, has led to decreased public, guests, tourists confidence in the safety of food and in the management of food-related hazards ${ }^{(4,5)}$. The primary goal of food risks management is the protection of public health by controlling risk as effectively as possible through the selection and implementation of appropriate measures ${ }^{(6)}$.

Though considerable attention has been paid to understanding consumer $\backslash$ guests perceptions of risk associated with different food hazards , less is known about consumer perceptions of the nature and effectiveness of food risk management ${ }^{(7,8,9)}$. This is important, as consumer confidence in risk management practices is likely to be influenced by what the public perceive as the best practice ${ }^{(10)}$. Perception is that process by which things, events and relationships become phenomenally " here ", " now" and real (11). Understanding perceptions and expectations of risk management are important steps for informing how best to communicate with the public about how food risks are managed. Indeed, the need to implement open and transparent communication with consumers about food safety procedures and decision making practices is now a priority in policy agendas ${ }^{(12,13)}$, and is part of a more general trend that goes beyond the food domain $(14,15)$

However, though increased transparency in regulatory measures may improve public confidence in risk analysis practices, such transparency may also provide opportunities for increased public scrutiny of the values and activities included in the practice of risk analysis including the values applied to risk management and risk assessment ${ }^{(16,17,18)}$.

This paper builds on recent qualitative and quantitative research that has revealed a variety of factors related to consumer perceptions of good food risk management.

The different factors are described below, identified is a number of factors related to perceptions of effectiveness of food risk management quality in a number of different European countries. ${ }^{(11)}$

\section{Literature review}

2.1Preventive risk management activities by risk regulators (proactive consumer protection PCP) 
Research has suggested that consumers prefer that regulatory authorities with responsibility for consumer protection direct their efforts towards preventing the occurrence of food safety incidents as opposed to adoption of a reactive approach. ${ }^{(19,20)}$

\subsection{Perceived transparency associated with the risk analysis process (Opaque and reactive risk management ORR)}

Both experts and consumers are of the same opinion that early identification of emerging food safety issues is of crucial importance in order to prevent them from developing into health risks. ${ }^{(21,22)}$ Perceptions of effective risk management activities are, to some extent determined by perceptions, that risk analysis practices are transparent.

\subsection{Communication about risk assessment processes (skepticism about risk assessment and risk communicational SCEP)}

Research has suggested that, though food safety experts perceive that consumers lack awareness of food safety issues, creating a need for further public information and education campaigns, many consumers report that they are reaching a situation of information over load in terms of the quantity of risk information that is important. ${ }^{(23)}$

2.4 Consumer trust in honesty and expertise of food risk managers (Honesty of food risk managers (TRUSTH)

Trust has been extensively studied in relation to consumer perceptions of food safety and food risk management ${ }^{(24,25,26)}$. Consumer trust in different actors and institutions responsible for guaranteeing and controlling food safety, as well as trust in the information provided by different information sources that communicate about food safety or food related risks, is considered important for consumer evaluation of the efficacy of food risk management practices..$^{(27,28)}$

\section{5 food risk management quality (FRMQ)}

Is the dependent construct which explains the consumers evaluation of the regulatory system in place to manage food hazards "Food risks are very well managed in our country", "When I buy food, I am certain that it is safe to eat, "and "I trust the regulatory system to protect me from food risks"

The conceptual model of this study was developed specifically to address the critical role of consumers 'cognitive constructs in determining their evaluation process our research model includes six constructs (table 1) ${ }^{(29-33)}$

As shown below: definition of the six constructions of FRMQ model ${ }^{(29-32)}$

\begin{tabular}{|c|c|c|}
\hline Variables & Definition & Previous \\
\hline \multirow[t]{5}{*}{$\begin{array}{l}\text { Proactive consumer } \\
\text { protection }(\mathrm{PCP})\end{array}$} & $\begin{array}{l}\text { The management systems that consumers perceive } \\
\text { to be functioning with respect to food safety }\end{array}$ & Van Dijk.(2008). ${ }^{(10)}$ \\
\hline & $\begin{array}{l}\text { - Consumer's perceptions of whether there is an } \\
\text { established system for controlling food risks }\end{array}$ & Frewer ,L.J.(2004).$^{(17)}$ \\
\hline & $\begin{array}{l}\text { - The rapidity of responses to food safety } \\
\text { problems }\end{array}$ & \\
\hline & - Efforts made to prevent food risks & \\
\hline & The efficient enforcement of food safety laws & \\
\hline \multirow[t]{2}{*}{$\begin{array}{l}\text { Opaque and reactive risk } \\
\text { management (ORR) }\end{array}$} & $\begin{array}{l}\text { Capture the concepts of responsiveness to food } \\
\text { safety problems }\end{array}$ & Houghton J.R.(2006) ..$^{(30)}$ \\
\hline & $\begin{array}{l}\text { Negative measures taken or lack of management } \\
\text { actions taken in food safety }\end{array}$ & \\
\hline
\end{tabular}




\begin{tabular}{|l|l|l||}
\hline $\begin{array}{l}\text { Skepticism in risk } \\
\text { assessment and } \\
\text { communication } \\
\text { practices (SCEP) }\end{array}$ & $\begin{array}{l}\text { Capture consumers doubts about food safety } \\
\text { assessment and the uncertainties surrounding this }\end{array}$ & (Krystallis A. 2007)..$^{(31)}$ \\
\hline $\begin{array}{l}\text { Trust in honesty of food } \\
\text { risk managers } \\
\text { (TRUSTH) }\end{array}$ & $\begin{array}{l}\text { The degree to which an audience perceives the } \\
\text { assertion made by a communicator that the speaker } \\
\text { considers valid }\end{array}$ & Hovland C.I. (1953)..$^{(32)}$ \\
\hline $\begin{array}{l}\text { Trust in expertise of } \\
\text { food risk managers } \\
\text { (TRUSTE) }\end{array}$ & $\begin{array}{l}\text { The extent to which a food risk manager is } \\
\text { perceived to be capable of making correct } \\
\text { assertions }\end{array}$ & Hovland C.I. (1953). ${ }^{(32)}$ \\
\hline $\begin{array}{l}\text { Food Risk Management } \\
\text { Quality (FRMQ) }\end{array}$ & $\begin{array}{l}\text { Consumers' evaluation of the regulatory system to } \\
\text { manage food hazards }\end{array}$ & Van Dijk. (2008)..$^{(10)}$ \\
\hline \hline
\end{tabular}

\section{Methodology:}

This study aims to evaluate the food risk management quality in Alexandria city through hotels and restaurants 'guests against historic and food safety (e.g. Food poisoning outbreak), and the food safety knowledge of guests about factors that contribute to food poisoning outbreaks.

The study used two questionnaires; the first evaluates the food risk management quality in Alexandria city through hotels and restaurants 'guests; the second evaluates food safety knowledge of the guests about the food poisoning outbreak as example of food risk management quality. In the first questionnaire, five point likert scale was used ( $1=$ strongly disagree to $5=$ strongly agree). The presentation order of the items was randomized to help overcome the fatigue effects about half of the items were reversed in polarity to control for respondent response bias. ${ }^{(29)}$ The construct was measured using items that reflect consumers 'perceptions of whether there is an established system for controlling food risks, the rapidity responses to food safety problems, the effort made in order to prevent food risks, and the efficient enforcement of food safety laws by the authorities. The opaque and reactive risk management scale (ORR) captures the concepts of responsiveness to food safety problem. The items concentrate on negative measures taken or lack of management actions taken in food safety. Skepticism about risk assessment and risk communication comprises items that capture consumers 'doubts about food safety assessment and the uncertainties surrounding. These incorporated two dimensions treated as two separate scales: trust in the honesty of food risk managers and trust in the expertise of food risk managers. The dependent construct "Food risk management quality" was measured using three items that reflect consumers "evaluation of the regulatory system in place to manage food hazards " Food risks are very well managed in our country " When I buy food, I am certain that it is safe to eat and I trust the regulatory system to protect me from food risks.

In the second questionnaire, every statement was scored "one" if the answer was correct, otherwise zero. Then every questionnaire as well as different parameters and items within them were given acceptable or unacceptable depending on their score and the percent score were as follows:-

1- Acceptable $\geq 50 \%$

2- Unacceptable $<50 \%$

The respondents were randomly chosen from guests of hotels and restaurants. The sample size comprised150 guests and a self-administered questionnaire method was employed. Data were collected during May 2015 to February 2016. At the end of the data collection process, a total of 125 questionnaires were gathered, used and finally coded. This represents $83.3 \%$ of the total distributed questionnaires.

The first questionnaire was divided into parts measuring the six constructs as follows: 


\section{Measurement scales}

\section{First: proactive consumer protection}

1- There is an established system for controlling food risks.

2- The authorities will respond quickly if a food safety problem appears.

3- The authorities put a lot of effort to prevent food risks.

4- Food safety laws are stringently enforced by the authorities.

\section{Second: opaque and reactive risk management}

1- There is no proper management of food hazards by the responsible authorities.

2- The authorities do nothing to protect consumers from food risks until a food safety crisis occurs.

3- Food poisoning has shown that the food risk management system is inadequate.

4- The authorities do not listen to consumer concerns about food safety.

5- Food safety controls that do exist are frequently ignored by food producers.

6- The authorities are hiding information about food hazards from consumers.

\section{Third: skepticism in risk assessment and communication practices}

1- The more research that is conducted, the more food safety problems are uncovered.

2- Scientists should be open with consumers if they are uncertain about food hazards.

3- The authorities need to learn more about food safety in order to manage food hazards.

4- The authorities should tell us what they do not know when they give advice about food safety.

\section{Fourth: honesty of food risk managers}

1- Food risk managers are biased when making decisions about food risk management.

2- Food risk managers distort information about food risk management.

3- Food risk managers do not provide factual information about food risk management.

4- Food risk managers do not have good track record of protecting the public.

5- Food risk managers were in the wrong in the past in their handling of food safety matters.

6- Food risk managers are not concerned about public welfare.

7- Food risk managers protect themselves and their own interests rather than consumers.

8- Food risk managers provide sensationalized information about food hazards.

9- Food risk managers are not trustworthy.

10- Food risk managers have a vested interest in promoting a particular view about food hazards.

11- Food risk managers are withholding information about food safety from the public.

\section{Fifth: Expertise of food risk managers}

1- Food risk managers are accountable to others if mistakes are made.

2- Food risk managers are experts in food risk management.

3- Food risk managers have the freedom to provide information to the public about food hazards.

4- Food risk managers are knowledgeable about food safety.

5- Food risk managers are responsible for managing food risks.

\section{Sixth: Food risk management quality}

1- Food risks are very well managed in our country.

2- When I buy food, I am certain that it is safe to eat.

3- I trust the regulatory system to protect me from food risks. 
The Second questionnaire evaluates the food safety knowledge of guests about factors that contribute to bacterial food poisoning outbreaks in Alexandria city.

The second questionnaire includes four main parameters described as follows:

\section{I- Source of food contamination}

1- Human as healthy persons, diseased person and carriers.

2- Insects and pests.

3- Environmental sources including air, soil and water.

4- Equipment and utensils.

5- Raw foods (including their role in contaminating ready to eat foods as well as the habit of eating raw foods. raw milk, shell, fish...)

\section{II- Cross-Contamination}

1- Including clean washed hands, prevention of contaminating foods from raw, avoidance of licking of fingers during cooking.

2- Washing of raw foods (vegetables and fruits).

3- Thermal processing (adequate thermal processing of foods and if boiling does not destroy all microbial forms present in foods).

4- Storage of foods (proper refrigeration of foods, proper thawing of frozen as well as avoidance of refreezing).

5- Handling of leftover foods (In cloudy proper refrigeration as well as adequate reheating).

\section{III- Personal hygiene}

1- Health and cleanliness (as avoidance of handling of foods during the course of different diseases, clean hands free from boils, abscesses and other lesions, keeping nails clean, short and unvarnished as well as keeping the hair covered and wearing separate clean light, colored clothing during food preparation.

2- Habits (Including avoidance of coughing and sneezing near uncovered foods, washing of hands before and after food preparation as well as avoidance of licking of fingers during tasting of foods.

\section{IV- Insect control and waste disposal}

1- Insect control.

2- Waste disposal.

\section{Statistical analysis}

Data After collection was, coded and fed to statistical software IBM SPSS version 20. The given graphs were constructed using Microsoft excel software.

Descriptive statistics: included the composite means and standard deviation for the numeric data; while percentage to describe the frequency of each category. Correlation analysis between different measured parameters was done using Pearson correlation coefficient to study the bidirectional relation between domains. Reliability was assessed using Cronbach's Alpha test. Significance of the obtained results was judged at $5 \%$ level $^{(33,34)}$

\section{Results}

The results generally confirm the importance of the identified factors, which help to explain relative perceptions of FRMQ.

In the following sections we consider participants' views regarding the factors previously identified as being related to perceptions of food risk management quality. 
Table (1): Descriptive Statistics, Number of Items, and Coefficients of Reliability and Coefficients for the six scales

\begin{tabular}{||l|l|c|c|c|c|c|c|c|c|c||}
\hline \multicolumn{1}{|c|}{\begin{tabular}{|} 
food risk measurement \\
scales
\end{tabular}} & Mean \pm SD & $\begin{array}{c}\text { No. } \\
\text { items }\end{array}$ & $\begin{array}{c}\text { Cronbac } \\
\text { h's Alpha }\end{array}$ & $\mathbf{1}$ & $\mathbf{2}$ & $\mathbf{3}$ & $\mathbf{4}$ & $\mathbf{5}$ & $\mathbf{6}$ \\
\hline $\mathbf{1}$ & $\begin{array}{l}\text { Proactive consumer } \\
\text { protection (PCP) }\end{array}$ & $\begin{array}{c}61.80 \pm 21.4 \\
5\end{array}$ & 4 & 0.726 & 1.000 & & & & & \\
\hline $\mathbf{2}$ & $\begin{array}{l}\text { Opaque and reactive risk } \\
\text { management (ORR). }\end{array}$ & $\begin{array}{c}48.83 \pm 20.9 \\
8\end{array}$ & 6 & 0.798 & $\begin{array}{c}0.471 \\
*\end{array}$ & 1.000 & & & & \\
\hline $\mathbf{3}$ & $\begin{array}{l}\text { Skepticism in risk } \\
\text { assessment and practices } \\
\text { (SCEP) }\end{array}$ & $\begin{array}{c}77.47 \pm 17.5 \\
5\end{array}$ & 3 & 0.700 & 0.080 & 0.076 & 1.000 & & & \\
\hline $\mathbf{4}$ & $\begin{array}{l}\text { Honesty of food risk } \\
\text { managers (THUSTH) }\end{array}$ & $\begin{array}{c}48.56 \pm 17.7 \\
7\end{array}$ & 10 & 0.822 & $\begin{array}{c}0.272 \\
*\end{array}$ & $\begin{array}{c}0.482 \\
*\end{array}$ & -2 & 1.000 & & \\
\hline $\mathbf{5}$ & $\begin{array}{l}\text { Expertise of food risk } \\
\text { managers (TRUSTE) }\end{array}$ & $\begin{array}{c}68.16 \pm 17.4 \\
2\end{array}$ & 5 & 0.711 & $\begin{array}{c}0.340 \\
*\end{array}$ & $\begin{array}{c}0.350 \\
*\end{array}$ & 0.168 & $\begin{array}{c}0.468 \\
*\end{array}$ & 1.000 & \\
\hline $\mathbf{6}$ & $\begin{array}{l}\text { Food risk management } \\
\text { quality }\end{array}$ & $\begin{array}{c}47.67 \pm 27.6 \\
3\end{array}$ & 3 & 0.769 & $\begin{array}{c}0.398 \\
*\end{array}$ & $\begin{array}{c}0.349 \\
*\end{array}$ & 0.035 & $\begin{array}{c}0.422 \\
*\end{array}$ & $\begin{array}{c}0.452 \\
*\end{array}$ & 1.000 \\
\hline
\end{tabular}

*These statistics are based on the entire sample $(n=125)$

Table (1) showed that correlation matrix of constructs and square root of average variance extracted (AVE), indicated the tool validity and reliability measures,

The models of domains, proactive consumer protection PCP , Opaque and reactive risk management ORR, Skepticism in risk assessment and practices SCEP, Honesty of food risk managers (TRUSTH), Expertise of food risk management quality, have high reliability coefficient and display excellent convergent and discriminant properties (Reliability, $\alpha$-Cronbach $0.72,0.79,0.70,0.82$ and 0.71 respectively).

The highest mean score in the measurement scales were " Skepticism in risk assessment, practices, expertise of food risk managers (TRUSTE) and Proactive consumer protection" with mean (M=77.47, 68.16 and 61.80 respectively). While the least mean scores were for" food risk management quality, honesty of food risk managers and opaque and reactive risk management" with means, $(M=47.67 \%, 48,56 \%$ and 48.83 $\%$ respectively).

Table (2): Distribution of the studied sample according to psychological factors influencing consumer evaluation of FRMQ

\begin{tabular}{|c|c|c|c|c|c|c|c|c|c|c|}
\hline \multirow[t]{2}{*}{ food risk measurement scales } & \multicolumn{2}{|c|}{$\begin{array}{c}\text { Strongly } \\
\text { agree }\end{array}$} & \multicolumn{2}{|c|}{ Agree } & \multicolumn{2}{|c|}{ Neutral } & \multicolumn{2}{|c|}{ Disagree } & \multicolumn{2}{|c|}{$\begin{array}{l}\text { Strongly } \\
\text { disagree }\end{array}$} \\
\hline & No. & $\%$ & No. & $\%$ & No & $\%$ & No. & $\%$ & No. & $\%$ \\
\hline \multicolumn{11}{|l|}{ Proactive consumer protection (PCP) } \\
\hline 1. There is an established system for controlling food risks. & 18 & 14.4 & 56 & 44.8 & 15 & 12.0 & 31 & 24.8 & 5 & 4.0 \\
\hline $\begin{array}{l}\text { 2.The authorities will respond quickly if a food safety problem } \\
\text { appears. }\end{array}$ & 27 & 21.6 & 45 & 36.0 & 23 & 18.4 & 23 & 18.4 & 7 & 5.6 \\
\hline 3.The authorities put a lot of effect to prevent food risk. & 22 & 17.6 & 46 & 36.8 & 27 & 21.6 & 26 & 20.8 & 4 & 3.2 \\
\hline 4.Food safety laws are stringently enforced by the authorities. & 33 & 26.4 & 37 & 29.6 & 26 & 20.8 & 22 & 17.6 & 7 & 5.6 \\
\hline
\end{tabular}




\begin{tabular}{|c|c|c|c|c|c|c|c|c|c|c|}
\hline \multicolumn{11}{|l|}{ Opaque and reactive risk management (ORR). } \\
\hline $\begin{array}{c}\text { 1.There is no proper management of food hazards by the } \\
\text { responsible authorities. }\end{array}$ & 14 & 11.2 & 49 & 39.2 & 18 & 14.4 & 37 & 29.6 & 7 & 5.6 \\
\hline The authorities do nothing to protect consumers from food risk & 9 & 7.2 & 40 & 32.0 & 14 & 11.2 & 44 & 35.2 & 18 & 14.4 \\
\hline $\begin{array}{l}\text { The BSE crisis has shown that the food risk management syster } \\
\text { is inadequate. }\end{array}$ & 15 & 12.0 & 51 & 40.8 & 24 & 19.2 & 23 & 18.4 & 12 & 9.6 \\
\hline $\begin{array}{l}\text { 4.The authorities do not listen to consumer concerns about food } \\
\text { safety }\end{array}$ & 10 & 8.0 & 39 & 31.2 & 27 & 21.6 & 29 & 23.2 & 20 & 16.0 \\
\hline $\begin{array}{l}\text { The food safety controls that do exist are frequently ignored by } \\
\text { food production. }\end{array}$ & 13 & 10.4 & 37 & 29.6 & 41 & 32.8 & 21 & 16.8 & 13 & 10.4 \\
\hline $\begin{array}{l}\text { The authorities are hiding information about food hazards from } \\
\text { consumers. }\end{array}$ & 14 & 11.2 & 28 & 22.4 & 34 & 27.2 & 33 & 26.4 & 16 & 12.8 \\
\hline \multicolumn{11}{|l|}{ Skepticism in risk assessment and practices (SCEP) } \\
\hline $\begin{array}{l}\text { 1.The more research that is conducted, the more food safety } \\
\text { problems are uncovered. }\end{array}$ & 56 & 44.8 & 50 & 40.0 & 14 & 11.2 & 4 & 3.2 & 1 & 0.8 \\
\hline $\begin{array}{l}\text { Scientists should be open with consumers if they are uncertain } \\
\text { about food hazards }\end{array}$ & 41 & 32.8 & 57 & 45.6 & 9 & 7.2 & 15 & 12.0 & 3 & 2.4 \\
\hline $\begin{array}{l}\text { The authority needs to learn more about food safety in order to } \\
\text { manage food hazards. }\end{array}$ & 41 & 32.8 & 63 & 50.4 & 15 & 12.0 & 5 & 4.0 & 1 & 0.8 \\
\hline \multicolumn{11}{|l|}{ Honesty of food risk managers (THUSTH) } \\
\hline $\begin{array}{l}\text { Food risk managers are biased when making decisions about } \\
\text { food risk management }\end{array}$ & 12 & 9.6 & 41 & 32.8 & 42 & 33.6 & 19 & 15.2 & 11 & 8.8 \\
\hline $\begin{array}{l}\text { 2.Food risk managers distort information about food risk } \\
\text { management . }\end{array}$ & 5 & 4.0 & 37 & 29.6 & 34 & 27.2 & 32 & 25.6 & 17 & 13.6 \\
\hline $\begin{array}{l}\text { 3.Food risk managers do not provide factual information about } \\
\text { food risk management }\end{array}$ & 6 & 4.8 & 48 & 38.4 & 25 & 20.0 & 32 & 25.6 & 14 & 11.2 \\
\hline $\begin{array}{l}\text { Food risk managers do not have good track record of protecting } \\
\text { the public. }\end{array}$ & 8 & 6.4 & 37 & 29.6 & 27 & 21.6 & 32 & 25.6 & 21 & 16.8 \\
\hline $\begin{array}{l}\text { Food risk managers have proven wrong in the past handling of food } \\
\text { food safety matters. }\end{array}$ & 18 & 14.4 & 49 & 39.2 & 36 & 28.8 & 17 & 13.6 & 5 & 4.0 \\
\hline 6.Food risk managers are not concerned about public welfare. & 11 & 8.8 & 39 & 31.2 & 31 & 24.8 & 36 & 28.8 & 8 & 6.4 \\
\hline $\begin{array}{l}\text { 7.Food risk managers protect themselves and their own interests } \\
\text { rather than consumers . }\end{array}$ & 9 & 7.2 & 39 & 31.2 & 26 & 20.8 & 29 & 23.2 & 22 & 17.6 \\
\hline 8.Food risk managers are not trustworthy. & 14 & 11.2 & 47 & 37.6 & 38 & 30.4 & 22 & 17.6 & 4 & 3.2 \\
\hline $\begin{array}{l}\text { Food risk managers provide sensationalized information about } \\
\text { food hazards. }\end{array}$ & 16 & 12.8 & 26 & 20.8 & 35 & 28.0 & 31 & 24.8 & 17 & 13.6 \\
\hline 0.Food risk managers are withholding information about food & 13 & 10.4 & 37 & 29.6 & 35 & 28.0 & 16 & 12.8 & 24 & 19.2 \\
\hline
\end{tabular}




\begin{tabular}{|c|c|c|c|c|c|c|c|c|c|c|}
\hline safety from the public. & & & & & & & & & & \\
\hline \multicolumn{11}{|l|}{ Expertise of food risk managers (TRUSTE) } \\
\hline $\begin{array}{l}\text { 1.Food risk managers are accountable to others (e.g., regulatory } \\
\text { bodies) if mistakes are made. }\end{array}$ & 25 & 20.0 & 48 & 38.4 & 28 & 22.4 & 19 & 15.2 & 5 & 4.0 \\
\hline 2.Food risk managers are experts in food risk management & 31 & 24.8 & 51 & 40.8 & 24 & 19.2 & 15 & 12.0 & 4 & 3.2 \\
\hline $\begin{array}{l}\text { Food risk managers have the freedom to provide information to } \\
\text { the public about food hazards }\end{array}$ & 23 & 18.4 & 49 & 39.2 & 32 & 25.6 & 14 & 11.2 & 7 & 5.6 \\
\hline 4.Food risk managers are knowledgeable about food safety & 34 & 27.2 & 53 & 42.4 & 29 & 23.2 & 7 & 5.6 & 2 & 1.6 \\
\hline $\begin{array}{l}\text { Food risk managers are responsible when it comes to managing } \\
\text { food risks }\end{array}$ & 37 & 29.6 & 54 & 473. & 26 & 20.8 & 6 & 4.8 & 2 & 1.6 \\
\hline \multicolumn{11}{|l|}{ Food risk management quality } \\
\hline 1.Food risks are very well managed in our country. & 13 & 10.4 & 29 & 23.2 & 23 & 18.4 & 26 & 20.8 & 34 & 27.2 \\
\hline 2.When I buy food, I am certain that it is safe to eat. & 23 & 18.4 & 32 & 25.6 & 23 & 18.4 & 30 & 24.0 & 17 & 13.6 \\
\hline 3.I trust the regulatory system to protect me from food risks. & 21 & 16.8 & 19 & 15.2 & 34 & 27.2 & 31 & 24.8 & 20 & 16.0 \\
\hline
\end{tabular}

Table (2) shows the distribution of the studied sample according to psychological factors influencing consumer evaluations of FRMQ (food risk measurement scales).

The majority of respondent (44.8\%) strongly agreed upon Skepticism factor in risk assessment and practices. Concerning the items, " scientists should be open with consumers if they are uncertain about a food hazards", and the authorities need to learn more about food safety in order to manage food hazards (32.81\%) of respondents strongly agreed upon them. While the least percentages were for the items, "honesty of food risk management" and" food risk managers distort information about food risk management" $4 \%$ and $4.8 \%$ respectively and "food risk managers do not have a good track record in protecting the public" $6.4 \%$.

As regards to items" the food risk management quality of food risk" was negatively related to food risk management quality in Alexandria represent the highest strongly disagree $27.2 \%$ followed by the factor of" honestly of food risk managers" to items "Food risk managers are withholding information about food safety from the public", $19.20 \%$.

Table (3) Distribution of the guests of hotels \&restaurants according to the knowledge of the guests about food poisoning outbreak

\begin{tabular}{||c|c|c||}
\hline $\begin{array}{c}\text { \% score of knowledge of the guests } \\
\text { about food poisoning outbreak }\end{array}$ & Min. - Max. & Mean \pm SD \\
\hline Sources of food contamination & & \\
\hline Human & $0.0-100.0$ & $73.20 \pm 32.09$ \\
\hline Equipment and utensils & $0.0-100.0$ & $94.40 \pm 23.08$ \\
\hline Environmental sources & $0.0-100.0$ & $90.40 \pm 29.58$ \\
\hline Insects and pets & $0.0-100.0$ & $96.80 \pm 17.67$ \\
\hline
\end{tabular}




\begin{tabular}{|c|c|c|}
\hline Raw foods & $0.0-100.0$ & $82.0 \pm 28.68$ \\
\hline $\mathbf{p}$ & \multicolumn{2}{|c|}{$<0.001^{*}$} \\
\hline \multicolumn{3}{|l|}{ Handling of foods } \\
\hline Cross contamination & $33.33-100.0$ & $81.33 \pm 20.91$ \\
\hline Washing of raw foods & $0.0-100.0$ & $91.20 \pm 28.44$ \\
\hline Thermal processing & $0.0-100.0$ & $72.80 \pm 32.07$ \\
\hline Storage of foods & $0.0-100.0$ & $86.80 \pm 23.88$ \\
\hline Handling of leftover food & $0.0-100.0$ & $90.08 \pm 18.60$ \\
\hline $\mathbf{p}$ & \multicolumn{2}{|c|}{$<0.001^{*}$} \\
\hline \multicolumn{3}{|l|}{ Personal hygiene } \\
\hline Health and cleanliness & $0.0-100.0$ & $93.28 \pm 17.77$ \\
\hline Habits & $0.0-100.0$ & $92.80 \pm 19.78$ \\
\hline $\mathbf{p}$ & \multicolumn{2}{|c|}{0.776} \\
\hline \multicolumn{3}{|l|}{ Insect control and waste disposal } \\
\hline Insect control & $0.0-100.0$ & $94.80 \pm 16.59$ \\
\hline Waste disposal & $33.33-100.0$ & $93.07 \pm 18.11$ \\
\hline $\mathbf{p}$ & \multicolumn{2}{|c|}{0.265} \\
\hline
\end{tabular}

*: Statistically significant at $\mathrm{p} \leq 0.05$

Table (3) shows the distribution of food safety knowledge among guests of hotels \&restaurants regarding food poisoning outbreak. It is clear from the table that insect control and waste disposal parameter had the highest mean score percent $(93.76 \pm 15.33)$, followed by personal hygiene had $(93.53 \pm 14.37)$, followed by handling of foods while the lowest $(84.57 \pm 15.98)$ was for the sources of food contamination parameter. (85.49 \pm 12.44$)$.

Concerning the items of sources of food contamination parameter, insects and pets had the highest mean score percent $(96.80 \pm 17.67)$ while the lowest was for human $(73.20 \pm 32.09)$ followed by raw foods $(82 \pm 28.68)$ and environmental sources $(90.40 \pm 29.58)$. There was a significant variation among the different items of handling of foods parameter at $\mathrm{p}<0.001$; thus washing of raw foods had the highest mean score

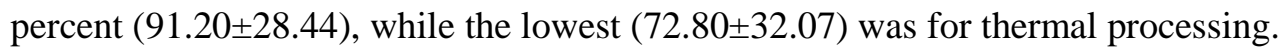

Again, there was a significant variation among the different items of personal hygiene parameter at $\mathrm{p}$ $<0.001$; thus health and cleanliness showed a mean score percent of $93.28 \pm 17.77$ followed by habits (92.80 \pm 19.78$)$, at the same time there was no significant variation at $\mathrm{p}=0.776$ between insect control and waste disposal parameter; the former showed a mean score percent of $94.80 \pm 16.59$, the latter $(93.07 \pm 18.11)$, also, there was no significant variation at $\mathrm{p}=0.265$.

Table (4) Distribution of the studied sample according to \% score of the dimensions

\begin{tabular}{|c|c|c|}
\hline Variable & Min. - Max. & Mean \pm SD \\
\hline Sources of food contamination & $25.0-100.0$ & $85.40 \pm 15.69$ \\
\hline
\end{tabular}




\begin{tabular}{|r|c|c||}
\hline Handling of foods & $41.67-100.0$ & $84.47 \pm 12.67$ \\
\hline Personal hygiene & $0.0-100.0$ & $93.14 \pm 16.29$ \\
\hline Insects control and waste disposal & $40.0-100.0$ & $93.76 \pm 15.33$ \\
\hline
\end{tabular}

Table (6) shows the distribution of food safety knowledge of guests of hotels and restaurants about food poisoning outbreak according to the $\%$ score. It is clear from the table that insect control \& waste disposal parameter had the highest mean score percent $(93.76 \pm 15.33)$ followed by personal hygiene $(93.14 \pm 16.29)$ and sources of food contamination $(85.40 \pm 15.69)$; the lowest mean score percent was for handling of foods $(84.47 \pm 12.67)$.

Table (5) Distribution of the studied sample according to acceptability of the dimensions

\begin{tabular}{|c|c|c|c|c|}
\hline \multirow[t]{2}{*}{ Variable } & \multicolumn{2}{|c|}{$\begin{array}{c}\text { Unacceptable } \\
(<\mathbf{5 0 \%})\end{array}$} & \multicolumn{2}{|c|}{$\begin{array}{c}\text { Acceptable } \\
(\geq \mathbf{5 0} \%)\end{array}$} \\
\hline & No. & $\%$ & No. & $\%$ \\
\hline Sources of food contamination & 1 & 0.8 & 125 & 99.2 \\
\hline Handling of foods & 1 & 0.8 & 125 & 99.2 \\
\hline Personal hygiene & 4 & 3.2 & 121 & 96.8 \\
\hline Insects control and waste disposal & 6 & 4.8 & 119 & 95.2 \\
\hline
\end{tabular}

Table (5) demonstrates the acceptability and unacceptability given to the guests of hotels and restaurants concerning their food safety knowledge.

Most of the guests (95.2-99.2\%) evaluted "acceptable" concerning all the food contamination items.

\section{Conclusion:}

The results presented here would suggest that, effective food risk management requires communication with consumers about what must be done to proactively protect consumers from different food hazards before the risks occur. In other words, confidence in risk management practices is determined by the adoption of a proactive approach to consumers' protection, and communication with consumers about how this proactive approach (i.e., informing consumers about what has been done to mitigate risks after they had occurred) is unlikely to generate consumer confidence in risk management activities. Ccommunication about risks management practices should be strong in the risk analysis process. A transparent process of risk management regarding how these activities are initiated and conducted is also important to consumers. Communication about how safety is maintained through application of food safety system, prompt responses on the part of risk managers if potential hazards are detected, and how good safety is enforced, is needed to develop and maintain consumer confidence in food safety. ${ }^{(46)}$ This paper enables policy makers to integrate societal concerns and values into risk management and communication regarding food safety and to enhance the public confidence in the authorities' approach to the food risk management.

\section{Recommendations:}

According to the results of the present study, the following recommendations should be put into considerations.

1- Designation of food safety educational programs.

-These programs should be directed to the general public with a special emphasis on house wives, students and food handlers. 
-These programs could be through mass media as well as through school curriculum.

\section{These programs should include the following:}

1. Sources of food contamination, proper handling of foods ,personal hygiene, insects and pets control ,and waste disposal.

2- Centers for surveillance and reporting of food poisoning should be established.

3- Investigation of food poisoning outbreaks should be intensified through public health authorities with cooperation with universities and research institutions to assess the magnitude of illnesses as well as factors contributing to them.

4- Upgrading and strengthening the already present laboratories for the accurate and rapid identification of various agents causing microbial food poisoning.

5- Sterile equipment and utensils necessary for the collection and transportation of clinical specimens should be available in every place where patients with food poisoning may be admitted.

3- Periodic training programs should be launched for those working on the laboratories of most recent methods of accurate and rapid identification of causative agents in microbial food poisoning.

4- Implementation of Hazard Analysis and Critical Control Points (HACCP) principles to ensure food safety in every place where foods are handled.

\section{References}

1- Frewer, L.,Miles, S.and Marsh R. (2002):The media and genetically modified foods:evidence in support of social amplification of risk .Risk Analysis,22:701-711.

2- Miles, S.; Brennan M.,Kuznessof S.; Ness M.; Ritson C.and Frewer L.J.(2004):Public Food Journal,106:9-22.

3- World Health Organization 2002.

4- Frewer, L. and Salter, B. (2002). Public attitudes, scientific advice and the politics of regulatory policy: the case of BSE. Science and public policy, 29(2): 137-145.

5- Verbeke, W., Viaene, J. and Guiot, O. (1999). Health communication and consumer behavior on meat in Belgium; Journal of health communication, 4(4), 345-357.

6- FAO/WHO, (1997). Risk management and food safety. FAO food and nutrition paper number 65. Available at ftp://ftp.fao.org/docrep/fao/w4982e00. pdf [accessed 25 February 2009].

7- Fife, S. C. and Rowe, G., (1996), Public perceptions of every day food hazards: a psychometric study. Risk analysis, 16(4), 487-500.

8- Miles, S. and Frewer, L.J. (2001). Investigating specific concerns about different food hazards higher and lower order attributes Food quality and preference, 12: 47-61.

9- Fisher, A.R.H.,. (2007). Food. Safety in person perception: the impact of negative and extreme behavior Journal of Personality and Social Psychology, 38: 889-906.

10- Van Dijk, H. (2008). Consumer responses to communication about food risk management. Appetite, 50(2-3), 340-352.

11- Hochberg, J. (1956). Perception: toward the recovery of a definition. Psychological review, 63(6): 400-405.

12- Millstone, E. and Van Zwanenberg, p. (2000). A crisis of trust: for science, scientists or for institutions? Nature Medicine, 6(12): 1307-1308.

13- Byrne, D. (2002). EFSA. Excellence, integrity and openness. In: Inaugural Meeting, Available at http://www.foodlaw.rdg.ac.uk/eu/doc-48. htm. [Accessed 25 February 2009].

14- Rowe, G., Hawkes, G. and Houghton, J. (2008). Initial UK public reaction to avian influenza analysis of opinions posted on the BBC website. Health, Risk and Society, 10(4): 361-384. 
15- Walls, J.; Pidgeon, N., Weyman, A. and Horlick-Jones,T. (2004). Critical trust: understanding lay perceptions of health and safety risk regulation. Health, Risk and Society, 6(2):133-150.

16- Jensen, K.K. and Sandoe, p. (2002). Food safety and ethics: the interplay between science and values, Journal of agricultural and environmental, Ethics 15:245-253.

17- Frewer, L.J. (2004). The public and effective risk communication. Toxicology letters, 149 (1-3), 391-397.

18- Wales, C. (2004). Country report-, united kingdom. Available from:http//www.trustinfood.org/SEARCH/BASIS/tifo/all/wp/DDD/58.pdf[Accessed 1 May 2007].

19- Wansink, B. (2004). Consumer reactions to food safety crises. Advances in food and Nutrition research, 48: 103-150.

20- Van K. and leef, E., 2006.Perception of food risk management among key stake -holders: results from across European study. Appetite, 47:46-63.

21- Marvin, H.J.P., (2009). A working procedure for identifying emerging food safety issues at an early stage implications for European and international risk management practices Food control, 20(4): 345-356.

22- Wentholt, M., submitted. The views of key stakeholders on an evolving food risk governance frame work: results from a Delphi study.

23- Krystallis, A.; Frewer L.; Rowe, G.; Houghton, J., Kehagia O. and Perrea,T.(2007):A perceptual divide? Consumer and expert attitudes to food risk management in Europe. Health Risk and Society, (9), 407-424.

24- Frewer, L.J. and Miles, S. (2001). Public trust and regulatory transparency. In: L.J. Frewer, R. Schifferstein, and E. Risvik, eds. Food choice in Europe. Berlin: Springer Verlag, 401-411.

25- Berg, L. and Holm, L. (2005). Trust in food safety in Russia, Denmark and Norway. European Societies, 7(1): 103-129.

26- De Jonge, J. (2007). Understanding consumers' confidence in the safety of food: Its two dimensional structure and determinants Risk Analysis, 27(3): 729-739.

27- Solvic, P. (1993). Perceived risk, trust and democracy. Risk analysis, 13(6): 675-682.

28- Solvic, P. (1999). Perceived risk, trust and democracy. In: G. Cvetkovigh and R.E lofstedt, eds. Social trust and the management of risk London: Earthscan, 42-52.

29- Herche, J. and Engelland, B. (1996). Reversed polarity items and scale uni-dimensionality. Journal of the academy of marketing science, 24: 366-374.

30- Houghton J.R; Van Klee, E.; Rowe G.and Frewer L.J. (2006):Consumer perception of the effectiveness of food risk management practices:A cross-cultural study .Health Risk and Society, 8:165-183.

31- Hovland, C.I.;Janis, I.L.and Kelley,H.H.(1953):Communication and Persuation:Psychological Studies of Opinion Change.Yale University Press,New Haven.

32- Kotz, S.; Balakrishnan, N.; Read; CB and Vidakovic B.(2006). Encyclopedia of statistical sciences. 2nd ed. Hoboken, N.J.: Wiley-Interscience.

33- Kirkpatrick, L.A.and Feeney BC.(2013). A simple guide to IBM SPSS statistics for version 20.0. Student ed. Belmont, Calif.: Wadsworth, Cengage Learning.

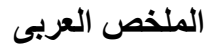

الهدف الرئيسى من إدارة مخاطر الغذاء هو حماية الصحة العامة عن طريق التحكم فى آثار هذه الدخاطر من خلال اختبار وتطبيق أفضل

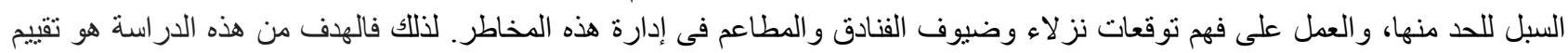

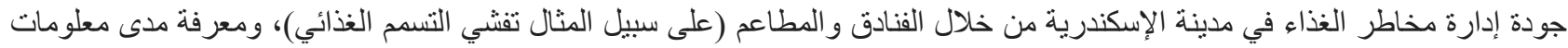

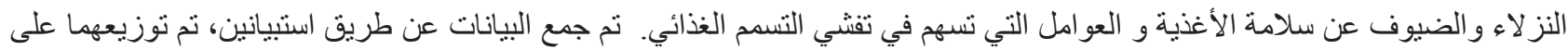
عينة من نز لاء الفنادق و المطاعم. نوضح النتائج بوجه عام أهمية العو امل التي تسهم فى التسمم الغذائى. 